CRADA Final Report (ORNL-CbevronTexaco-Phillips, 1999)

\# 574

\title{
Enzymatic Upgrading of Heavy Crudes via Partial Oxidation or Conversion of PAHs
}

\author{
A Final Report submitted to the \\ Office of Fossil Energy, Department of Energy, \\ July 2002
}

DOE CONTACTS: KATHY STIRLING and DEXTER SUTTERFIELD

\author{
By \\ Abhijeet P. Borole, Ph.D. \\ Brian H. Davison, Ph.D. \\ Tanya Kuritz, Ph.D. \\ Oak Ridge National Laboratory
}

Industrial Collaborators:

Robert Shong, Ph.D.

ChevronTexaco

Dan Hagewische, Ph.D.

ChevronTexaco

Gary Jenneman, Ph.D.

Phillips Petroleum Company 


\section{Contents}

Abstract

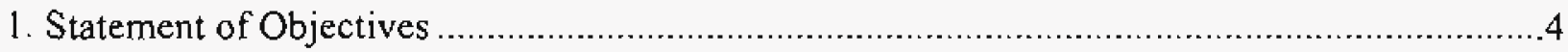

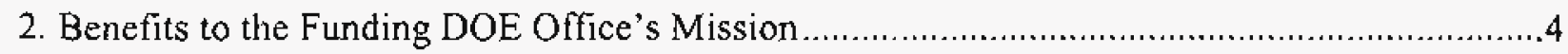





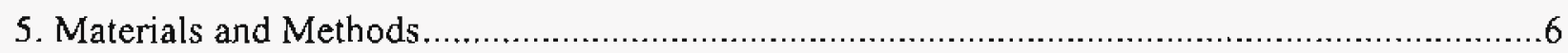

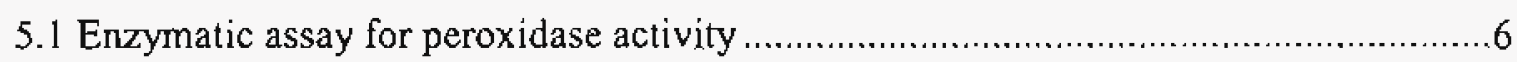

5.2 Chemical modification of enzymes: .................................................................... 7

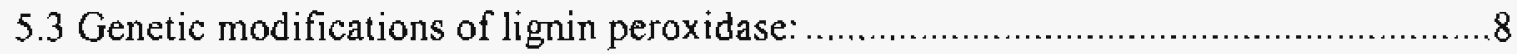

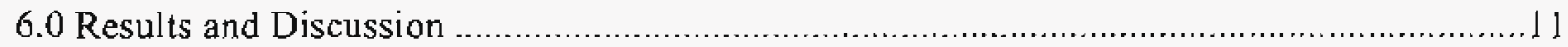



6.2 Thermodynamic analysis of enzymatic reactions ........................................ 12

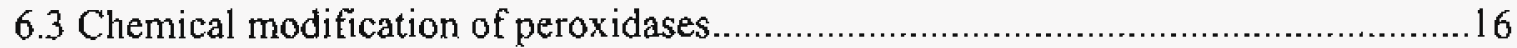

6.4 Genetic engineering of lignin peroxidase: .............................................. 20

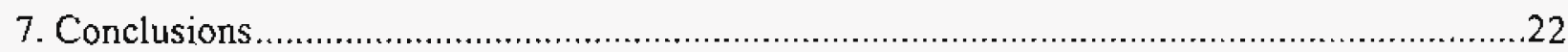



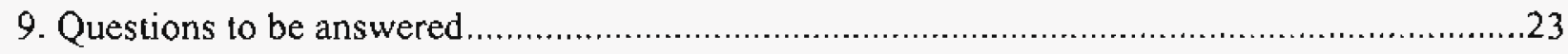

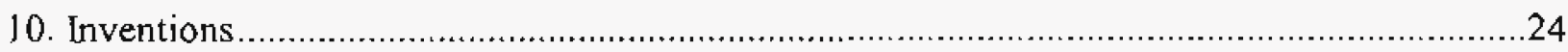

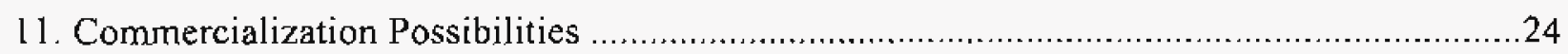



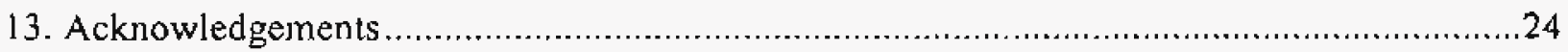









\begin{abstract}
The objective of this program was to investigate new enzyme-based technologies for upgrading of heavy oils. Enzymes were selected for screening from those capable of conversion of polyaromatic hydrocarbons (PAHs) reported in the literature. Oxidative reactions of PAHs using hydrogen peroxide as ал oxidant with conversion to partially oxidized products were used. The enzymes (lignin peroxidase, cytochrome c) were tested in various organic solvents and found to loose activity in pure organic solvents. A thermodynamic aralysis revealed lack of effective interaction between the substrate and enzyme as the cause for low activity. The protein cytochrome c was modified to work in organic media by chemical hydrophobic group attachment. Two different modifications were made: attachment of polyethylene glycol (PEG) and alkyl groups. Alkyl groups, being small could be attached at interior locations within the core of the enzyme and possibly near the active sile. Increase in the threshold solvent concentration where maximum enzyme activity occurred indicated potential of this strategy for effective enzyme-substrate interaction. Further improvements in enzyme activity called for other diverse methods due to the unavailability of sufficient chemical modification sites. Genetic techniques were therefore explored for further improvements. These experiments focused on cloning of a gene for the fungal enzyme lignin peroxidase (lip) into yeast Pichia pastoris, which would allow easy manipulation of the gene. However, differences in the fungal and yeast cellular machinery impeded significant expression of the fungal enzyme. Several strategies were explored to allow higher-level expression of the enzyme, which was required for enzyme improvement. The strategies used in this investigation are described in the report.
\end{abstract}

Industrial in-kind support was available throughout the project period. Review of the research results was carried out on a regular basis (bimonthly reports and annual meetings) followed by suggestions for improvement in ongoing work and direction for future work. A significant portion of the industrial support was in the form of technical consultation and expert advice via meetings and phone conversations.

\title{
1. Statement of Objectives
}

The following goals were pursued in this project:

1. Assess the potential of enzymatic upgrading of heavy oils

2. Identify ways to activate and stabilize enzymes in organic media

3. Study improvement of enzyme performance via genetic engineering

\section{Benefits to the Funding DOE Office's Mission}

Due to the increasing API gravity of crudes being produced in the United States and elsewhere, there is a need to develop methods to use such crudes in the petroleum industry. This will help reduce the reliance of US on foreign oil for energy needs. The goal of this project was to investigate the applicability and potential of enzyme-based processes for upgrading of heavy crudes. Improving yield and efficiency of producing transportation fuels from heavy crudes is part of DOE Fossil Energy's mission. Developing biotechnology-based solutions and finding the niche areas where biotechnology can be beneficially applied in the petroleum industry is a long 
term goal of this project.

\section{Technical Discussion of Work}

The project involved demonstration of proof of principle of enzyme-based processes for crude oi] applications. Enzymes capable of oxjdizing polyaromatic hydrocarbon (PAHs) molecules present in petroleum were selected for development as biocatalysts. The enzymes were modified with hydrophobic groups and polymers to make them active and stable in organic media. Initial tests were conducted with pure solvents to facilitate identification of products and tracking of reaction progress. A themodynamic analysis of the enzymatic process was conducted to understand the limiting factors of biotransformation in organic media. The modified enzymes were tested in various aqueous mixtures of organic solvents to demonstrate improvement in activity. To obtain further improvements, more versatile and effective techniques were required. The enzyme lignin peroxidase was selected as a candidate for improvements via genetic engineering. This enzyme is originally expressed in a fungal host, and therefore, it was necessary to clone it into another host to allow genetic manipulations. Pichia pastoris was selected as the host to express the enzyme, due to its capability to express heterologous proteins. However, very low levels of expression were obtained and therefore, methods such as directed evolution had to be explored. The details of these experiments are described in the following sections.

\section{Introduction}

Heavy crudes are commonly recalcitrant to conventional methods of refining due to the chemical stability of the asphaltentic groups as well as the viscosity of the oil. This recalcitrance is imparted largely by polyaromatic linkages within the asphaltentic moieties. The exact structure of the asphaltenic fraction of heavy crudes and how this structure contributes to increased viscosity has not been fully elucidated due to its complex character. It has been speculated that the highly aromatic asphaltenic groups may "layer" upon themselves to increase their stability and the macroscopic viscosity [1]. Strausz [2] identified components of asphaltene as fluorenes, alkanes, and alkyl substituted benzenes, naphthalenes, biphenyls, anthracenes and phenanthrenes. Organic sulfur within these asphaltenic groups occurs as cyclic sulfides and alkyl and polyaromatically substituted thiophenes. Biocatalysts such as Rhodococcus IGTS 8 are capable of removing sulfur from dibenzothiophene and alkyl substituted diberzothiophenes [3], [4] but are unable to affect desulfurization activity upon the majority of higher molecular weight sulfur compounds present in the crude oil [5]. This recalcitrance to biological action is perhaps attributable to both the steric protection of the organic sulfur via aromatic substitution of thiophenic groups and the high viscosity due to asphaltenic stabilization.

Biological processing of petroleum feedstocks offers an attractive alternative to themochemical treatment due to the comparatively mild conditions, high substrate and product specificity, and resistivity to catalyst fouling agents afforded by biological systems. Indeed, enzymes have been demonstrated to be capable of selectively oxidizing a number of the polyaromatic structures comprising asphaltene. Some of these reactions are actually the initial steps in the natural biodegradation of aromatic compounds. Such reaction pathways lead to break down of the molecules one carbon at a time. Use of enzymes from the initial steps in the pathway can potentially lead to opening of the ring stucture and possibly molecular weight reduction of the large polyaromatic structures. In addition, the partial oxidation of these structures may destabilize the 
stacking of asphalteric layers, serving to decrease the oil's viscosity. Partial oxidation may also render $\mathrm{S}, \mathrm{N}, \mathrm{Ni}$, and $\mathrm{V}$ groups more susceptible to further biological or conventional treatment.

The polyaromatic structures and PAHs are substrates for the enzyme ligninase from the white-rot fungus Phanerochaele chrysosporium [6]. The reaction products contain hydroxyl and keto groups which may serve to de-stabilize asphaltene stacking. While such reactions have been demonstrated using the native lignin peroxidase in water miscible solvents such as methanol, the stability of the native enzyme in these solvents is limited. Crude oil presents a much harsher environment for the enzyme causing very limited enzymatic activity and rendering an enzymatic process for crude oil upgrading unrealistic. Previous research in our group has demonstrated that chemical modification of enzymes can render them both soluble and active in organic solvents [7]. By attaching polyethylene glycol groups to the enzyme hydrogenase, it has been demonstrated that the enzyme retained activity in pure toluene and was more than 10 -fold active than the same enzyme in water [8]. Further modification of ligninase has demonstrated an 11 fold augmentation in the dechlorination of pentachlorophenol in acetonitrile / water [7].

The objective of this work was to evaluate the ability of enzymes, which have been modified to make them catalytically active and chemically stable in crude oil to upgrade both the quality of heavy crudes and decrease their recalcitrance to further processing. Peroxidases, which have been shown to convert polyaromatics to their respective quinones were investigated for bioconversion of polyaromatic structures in organic media. Two enzymes from the peroxidase class of enzymes were used, ligninase and cytochrome c. The first year of the work was focused on chemical modification of the enzymes to demonstrate improved activity in organic media. In the second part of the project genetic modification of the enzyme ligninase was undertaken. Due to the difficulty of working with the original fungal host, $P$. chrysosporizm, the enzyme was cloned into the yeast Pichia pastoris. The gene was then modified via directed evolution to improve expression.

\section{Materials and Methods}

\subsection{Enzymatic assay for peroxidase activity}

5.1.1 Cytochrome $c$ with pinacyanol chloride: The activity of cytochrome c was determined using a spectrophotometric assay. Change in absorbance of the substrate, pinacyanol chloride $(0.0013 \mathrm{mM})$ at $603 \mathrm{~nm}$ in a $1 \mathrm{~mL}$ reaction mixture containing potassium phosphate buffer was measured. The reaction was started by adding either of $1.62 \mu \mathrm{M}$ cytochrome $\mathrm{c}$ or $1.0 \mathrm{mM}$ hydrogen peroxide. Extinction coefficient for pinacyanol chloride used was $82.35 \mathrm{mM}^{-1} \mathrm{~cm}^{-1}$.

5.1.2 Cytochrome c with pyrene: The reaction was conducted in a $1 \mathrm{~mL}$ spectrophotometer cuvelte containing pyrene $(0.01 \mathrm{mM})$, cytochrome $\mathrm{c}(1.62 \mu \mathrm{M})$, potassium phosphate buffer $(50$ $\mathrm{mM}, \mathrm{pH}$ 6.1) and hydrogen peroxide ( $1 \mathrm{mM}$ ). The absorbance was measured at $335 \mathrm{~nm}$ using an extinction coefficient of $32.6 \mathrm{mM}^{-1} \mathrm{~cm}^{-1}$.

5.1.3 Ligninase with veratryl alcohol: This is the standard assay used for ligninase. Reaction was conducted in a $1 \mathrm{~mL}$ volume of succinate buffer $(40 \mathrm{mM}, \mathrm{pH} 4.0)$ with $2 \mathrm{mM}$ veratryl alcohol, $0.26 \mu \mathrm{M}$ Ligninase and $0.4 \mathrm{mM}$ hydrogen peroxide. Absorbance was measured at 310 $\mathrm{nm}$ using an extinction coefficient of $9.3 \mathrm{mM}^{-1} \mathrm{~cm}^{-1}$. 
5.1.4 Ligninase with pyrene: Reaction was conducted in succinate buffer $(40 \mathrm{mM}, \mathrm{pH} 4.0)$ with $0.01 \mathrm{mM}$ pyrene, $0.26 \mu \mathrm{M}$ Ligninase and $0.4 \mathrm{mM}$ hydrogen peroxide. The change in absorbance of pytene was measured at $335 \mathrm{~nm}$.

5.1.5 Horseradish peroxidase (HRP) with guajacol: Reaction was conducted in $50 \mathrm{mM}$ phosphate buffer, $\mathrm{pH} 6.1$, with $0.0 .5 \mathrm{mM}$ guaiacol, $30 \mathrm{nM} \mathrm{HRP}$, and $0.5 \mathrm{mM}$ hydrogen peroxjde. The increase in absorbance at 470 num (formation of product) was measured.

5.1.6 Enzyme assay in organic media: Erzyme assays in organic solvents were conducted using the same protocol given above, except for the buffer. In experiments with aqueous-miscible organic solvents, the solvent concentration ranged from $5-100 \%$ of the solvent and the rest being the assay buffer. In experiments with immiscible solvents, two types of experiments were conducted. The first experiment was done using a solvent saturated with the buffer, and the second experiment was done using 5-10\% buffer as a second phase. The PAHs used in the experiments were anthracene, dibenzothiophene, pyrene and methyl anthracene.

\subsection{Chemical modification of enzymes:}

The chemical modification was done using primarily three different agents: PEG, alkyl aldehyde and benzaldehyde. The protocols are given below

5.2.1 PEG modification: The activated from of polyethylene glycol was purchased from Shearwater polymers, Huntsville, AL. Two different activated PEGs were used: methoxy PEG succinimidyl succinate (MPSS) and PEG nitrophenyl carbonate (n-PEG). The protein, cytochrome $c$ was mixed with MPSS in a ratio of $1: 50$ or $1: 500$ (molar ratio, $0.1 \mathrm{mg}$ of protein + $19 \mathrm{mg}$ of MPSS) in a phosphate buffer at $\mathrm{pH} 8.0$ and stimed for 48 hours at $4 \mathrm{oC}$. The modified protein was separated from the unmodified protein using size exclusion column chromatogaphy (Sephadex G-75). Deionized water was used as the mobile phase. The fraction containing the modified enzyme was lyophilized as stored at $-200 \mathrm{C}$. The modification with n-PEG was done as follows: The protein (6.8 $\mathrm{mg}$ cytochrome c) was mixed with $66 \mathrm{mg}$ of $\mathrm{n}-\mathrm{PEG}$ in a $\mathrm{pH} 8.6$ phosphate buffer and stirred for 2 hours at room temperature. The product was washed with $\mathrm{pH}$ 6.1 phosphate buffer in an ultrafiltration cell with $10 \mathrm{k} \mathrm{Da}$ membrane to remove the byproducts / salts and then lyophilized and stored at $-200 \mathrm{C}$.

5.2.2 Alkyl modification: The attachment of alkyl group was carried out using a reductive alkylation procedure [9]. Two agents were used for modification: acetaldehyde and propionaldehyde. The modification reaction consisted the following: $2.5 \mathrm{mg}$ of enzyme, $1 \mathrm{~mL}$ of $40 \mathrm{mg} / \mathrm{ml}$ alkyl aldehyde solution in ethanol, $30 \mathrm{mg}$ sodium cyanoborohydride and $10 \mathrm{~mL}$ of phosphate buffer $\mathrm{pH} 6.1$. The reaction mixture was stired for 16 hours, followed by ultrafiltration through a $10 \mathrm{k}$ Da membrane to separate the reagents. The purified enzyme was lyophilized and stored at $-200 \mathrm{C}$.

5.2.3 Benzyl modification: This modification procedure was very similar to the alkyl modification. Instead of the alkyl aldehyde, benzaldehyde was used. The modified protein was found to precipitate in aqueous solution and was therefore was easily separated by centrifugation. 


\subsection{Genefic modifications of lignin peroxidase:}

The gene for the enzyme lignin peroxidase from Phaenerocheate chrysosporium was obtained from Dr. Nancy Da'Silva, University of Califomia, Irvine. The lignin peroxidase gene (lip) was originally isolated by Dr. Tien, Penn State University, who was also notified regarding the exchange. The gene was provided as a plasmid pBSH2 in E. coll (Figure 1 and 2). The enzyme is not expressed in an active form in $E$. coli, therefore, it was necessary to express it in a host that would allow heterologous expression. The host chosen for cloning the lip gene was Pichia pastoris. The advantages of this host include 10-100 fold higher expression of heterologous proteins, capability to do post-Iranslational modifications such as glycosylation and successful expression of a variety of heterologous proteins with appropriate protein folding (based on literature reports, [10]).

Figure 1. Plasmid DNA carrying the lip gene (obtained from Dr. Da'Silva)


GtcgcttgcccogacggcgtgcACACTGCTTCAacgcggegtgctgtgcatggttcccggtcctcga tgat

AtccagcagaacctcttccacggtggccagtgcggtgeCgaggcccacgaggccettcgtatggtcttcca cgact

CcatcgctatctcgcccaagcttcagtcgcagggcaagTttggcggcggcggcgcggacggctcgatcat cacctt

CtcctcgatcgagaccacgtaccacccgaacatcggcCtcgacgaggtcgtcgccatccagaagccgttca tcge

GaagcacggcgtcacgcccggcgacttcatcgcgttcGccggtgccgtcggcgtgagcaactgcccggg $\mathrm{cgcg}$

CcgcagatgcagttcttcctcggecgccccgaggcgaCgcaggctgcccccgacggtctcgtgcccgagc cctt

CcacaccatcgatcaggttctcgctcgcatgcttgatgctGgcggcttcgacgagatcgagactgtctggct getctc

TgcccactccatcgcggctgcgaacgacgtcgacncgAacatctccggcctgccgttcgactccaaccct ggcca

GttcgactcccagttcttngtcgagacgcaGCTCCGCGGTACCGCATTCCCtggcaagaccggcat Ccagggcaccgtcatgtcccgctcaagggcgagatgcgtctgcagacggaccacttgttcgcgcgcgac tcge

Gcacggcgtgcgagtggcagtccttcgtcaacaaccagacgaagctgcaggaggacttccagttcatcttc acg

Gcgctctcgaccctcggccacgacatgaacgccatgatcgactgctccgaggtcatccccgcgcccaagc $\mathrm{ccg}$

Tcaacttcggcccgtcgttcttccccgccggcaagacgcacgccgacatcgagcaggcttgcgcgtccac gccg ttcccgacgctcatcaccgcccetggtccetctgcgtccgtcgetcgcatcccgccgccgecgtccccaa ctaa

Figure 2. The gene sequence of lip cDNA from Dr. Ming Tien.

5.3.1 Cloning of lip into E. coli DH5 $\alpha$ : Standard molecular biology techniques [11] were used to isolate plasmid DNA from $E$. coli. Initial preparations were made with the boiling method, followed by restriction with enzyme EcoRI to isolate the lip gene. The vectors $\mathrm{pPICZ}$ and pPICZ $\alpha$ series obtained from Invitrogen, Carlsbad, CA were restricted with EcoRI and dephosphorylated with Calf intestinal phosphatase and ligated to the lip gene obtained from pBSH2. The ligation mixture contained $2 \mu \mathrm{L}$ lip gene, $I \mu \mathrm{L}$ vector, $1 \mu \mathrm{L} 10 \mathrm{X}$ ligation buffer and $1 \mu \mathrm{L}$ ligase enzyme $+5 \mu \mathrm{L}$ sterile water. The mixture was incubated at $37^{\circ} \mathrm{C}$ for one hour and transformed into E. coli DHS $\alpha$.

5.3.2 Cloning of lip via PCR: Polymerase chain reaction ( $P C R$ ) was used to generate the lip 
gene from $\mathrm{pBSH} 2$. The primers used were as follows:

\begin{tabular}{|l|l|}
\hline Table 1. Primers used for generating lip gene product. \\
\hline Primer name & Primer sequence \\
\hline H2DIR ALPHA & 5'-GAATTCgtcgettgccccgacggcgtg-3' \\
\hline H2DIR & 5'-GAATTCTAatggcgttcaagcagctcctc-3' \\
\hline H2REV ALPHAB & 5'-tctagattgggggacggcggcggg-3' \\
\hline H2REV AC & 5'-ctcgagttattagttgggggacggcgg-3' \\
\hline
\end{tabular}

The protocol for PCR was as follows: Reaction volume: $30 \mathrm{~mL}$ containing $1 \mathrm{~mL} 100 \mathrm{mM}$ dNTP, $3 \mathrm{~mL} 10 \mathrm{X}$ Sigma PCR buffer, 50 pmol of each primer, 5 fmol DNA template pBSH2, $1 \mathrm{~mL}$ Sigma or Thermopol Taq polymerase and $19.5 \mathrm{~mL}$ sterile water. The PCR program was as follows: 5 min $95^{\circ} \mathrm{C}$ followed by 35 cycles of $1 \min 95^{\circ} \mathrm{C}, 1 \min 56^{\circ} \mathrm{C}, 1 \min 30 \sec 72^{\circ} \mathrm{C}$ followed by a 5 -min extension at $72^{\circ} \mathrm{C}$. The gene product was ligated into pCR2.1-TOPO or $\mathrm{PBAD}-\mathrm{TOPO}$ from Invitrogen vectors using the A overhangs. The ligated plasmids were then transformed into $E$. coli $\mathrm{DH} 5 \alpha$ or Top 10 strain by chemical transformation.

5.3.3 DNA analysis: Plasmid DNA was isolated from E. coli strains by either boiling method or by Promega's wizard prep method. The isolated DNA was then restricted using restriction enzymes and analyzed by gel electrophoresis ( $0.7 \%$ agarose gel) to identify presence of lip gene or to determine the orientation of the cloned gene.

5.3.4 Cloning of lip in Pichia pastoris: After successful cloning of LiP in E. coli (as determined by analysis gene insert isolated from $E$. coli plasmid by gel electrophoresis), the gene was transferred from the Invitrogen plasmid into a vector pPICZ, which could be transformed into the yeast Pichio pastoris. This plasmid carries the inducible AOX1 promoter which is used for protein expression. The plasmid was linearized using Sacl prior to transformation to allow its recombination into the Pichia genome.

\subsubsection{Error prone PCR experiments for LiP mutation}

The goal of this subtask was to modify the lip gene and create molecular diversity starting from one gene. Error-prone PCR was used to create point mutations in the gene. The procedure was a modification of that provided by Zhao etal, 1997 [12], [13]. The protocol was as follows:

1. Prepare purified plasmid DNA

2. Prepare a $5 \mathrm{X}$ mutagenic buffer containing $17.5 \mathrm{mM} \mathrm{MgCl}_{2}, 100$ mM Tris (pH $\left.9.5,23^{\circ} \mathrm{C}\right)$

3. Prepare a $25 X$ deoxymucleoside triphosphate (dNTP) mix containing $5 \mathrm{mM}$ dGTP, $5 \mathrm{mM}$ dATP, (dAGTP)

4. Prepare a second $5 \mathrm{X}$ deoxynucleoside triphosphate (dNTP) mix containing $5 \mathrm{mM} \mathrm{dCTP}, 5 \mathrm{mM}$ dTTP, (dCTTP)

5. Prepare a $5 \mathrm{mM}$ solution of $\mathrm{MnCl} 2$

6. Prepare a $10 \mathrm{X}$ solution of DNA template, i.e., $-6 \mathrm{ng} / \mu \mathrm{l}$ soution of the plasmid DNA.

7. Prepare a $6 \mathrm{X}$ primer mix containing $10 \mathrm{pmol} / \mu \mathrm{J}$ of reverse and forward primers.

8. Combine $6 \mathrm{ml}$ mutagenic buffer, $6 \mathrm{ml}$ dCTTP, $1.2 \mathrm{ml}$ dAGTP, 3.0 
ml DNA template, $5 \mathrm{ml}$ primer mix, and make it up to $30 \mathrm{ml}$ with sterile distilled water. Mix the contents by gentle tapping.

9. Add 0.9 uL $\mathrm{MnCl} 2$, and mix well by tapping.

10. Add $0.3 \mathrm{ml}$ Taq polymerase and mix gently.

11. Add an drop of oil to cover liquid surface and start PCR with the following parameters: : 5 min $94{ }^{\circ} \mathrm{C}$ followed by 35 cycles of 1 $\min 94^{\circ} \mathrm{C}, 1 \min 50^{\circ} \mathrm{C}, 1 \min 30 \mathrm{sec} 72^{\circ} \mathrm{C}$ followed by a $30-\mathrm{min}$ extension at $72{ }^{\circ} \mathrm{C}$

The mutation frequency defined as average mutations per gene is a function of $\mathrm{Mn}$ concentration. Lip gene has J.3k base pairs. A $0.5 \%$ frequency means $6-7$ mutations. For the above PCR, the mutation frequency chosen was $0.15 \%$, resulting in about 2 mutations per gene.

\subsection{Results and Discussion}

\subsection{Activity of enzymes in organic solvents}

Partial oxidation of pyrene to pyrenediol by cytochrome $c$ was studied in non-polar and aqueousmiscible organic solvents. Conversion of polyaromatic hydrocarbons such as pyrene by cytochrome $c$ was reported to occur in 10\% acetonitrile-water mixtures previously [14]. This was confirmed in our laboratory (Figure 3). Experiments were conducted to investigate the conversion of PAHs at higher solvent concentrations and in pure organic solvents using lyophilized proteins. Pyrene conversion did not occur in pure toluene, acetonitrile and kerosene. Addition of up to $1 \%$ water did not improve conversion. Further experiments were conducted at various acetonitrile fractions in a solvent-buffer mixture. The results are shown in Figure 4 . Such behavior has been observed by Vazquez-Duhalt [14] for similar reactions using pinacyanol chloride as the substrate and cytochrome $\mathrm{c}$ as the catalyst. Deactivation of cytochrome $\mathrm{c}$ at $50 \%$ acetonitrile is one of the possibilities which can explain the behavior, however, our results (Figure 4) as well as that reported elsewhere [14] show that cytochrome $c$ is catalytically active in at least up to $80 \%$ acetonitrile. This suggests that the reason for lack of pyrene conversion at $50 \%$ is not protein deactivation.

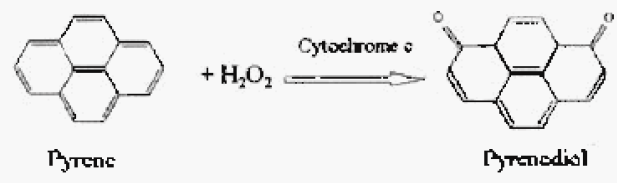

Figure 3. Biochemical reaction of partial oxidation of pyrene by cytochrome c. 


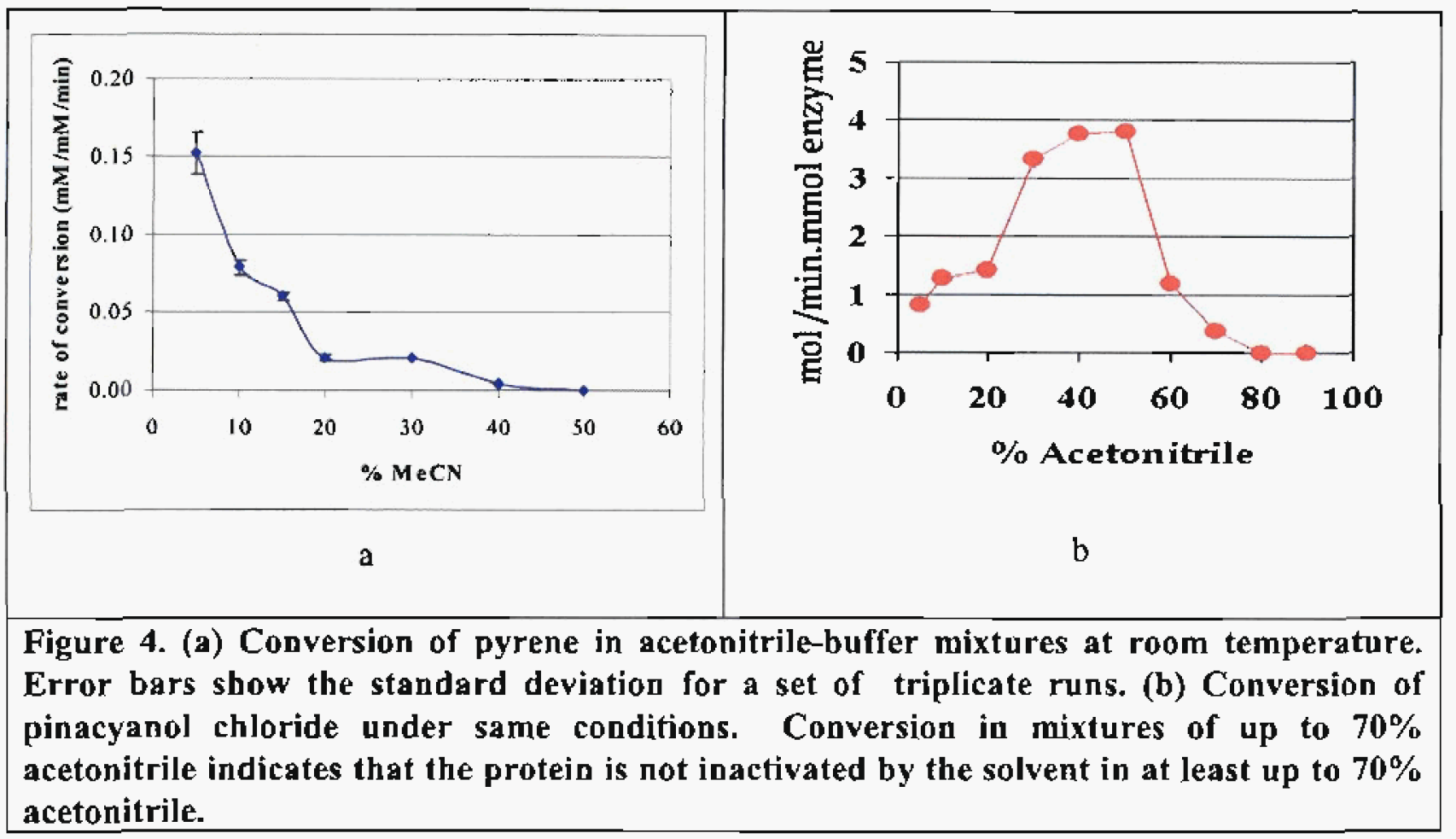

\subsection{Thermodynamic analysis of enzymatic reactions}

In order to investigate the reasons for lack of pyrene conversion above $50 \%$ acetonitrile, a detailed themodymamic analysis of the enzymatic reaction was conducted. Consider the reaction given below:

$\mathrm{E}+\mathrm{S} \leftrightarrow \mathrm{ES} \leftrightarrow \mathrm{ES}^{\ddagger} \rightarrow$ Products

The rate constant for the reaction is given as kcav/Km [15]. In terms of the transition state theory, the equilibrium constant between $E+S$ and the transition state $E S^{\ddagger}$ is proportional to the activation energy $\Delta \mathrm{G}_{\mathrm{T}}{ }^{\ddagger}$ of $\mathrm{kcav} / \mathrm{Km}$.

The observed free energy for an enzymatic reaction can be determined experimentally from $\mathrm{kcat} / \mathrm{Km}$ via the Arrhenius relationship, where $k$ is the transmission coefficient, $k$ is the Boltzmarn's constant, $T$ is the absolute temperature, $h$ is the Planck's constant and $R$ is the gas constant.

$\frac{k_{r a t}}{K_{m}}=\kappa\left(\frac{k T}{h}\right) \exp \left(\frac{-\Delta G_{a b:}^{\dagger}}{R T}\right)$

Substituting for $\Delta \mathrm{G}_{\text {obs }}{ }^{\ddagger}$, we have, 
$\ln \left(\frac{k_{c a t}}{K_{m}}\right)=\ln \kappa+\ln \left(\frac{k T}{h}\right)+\frac{\Delta S_{m b s}^{\ddagger}}{R}-\frac{\Delta H_{w b s}^{\ddagger}}{R T}$

Plotting $\ln (\mathrm{kcat} / \mathrm{Km})$ vs. inverse temperature (Figure 5) gives a straight line with a slope and $y$ intercept as follows:

Slope $=\frac{\Delta H_{\text {ohs }}{ }^{\ddagger}}{R}$

and y-intercept $=\ln \kappa+\ln \left(\frac{k T}{h}\right)+\frac{\Delta S_{\text {oby }}^{\prime}}{R}=\ln \left(\frac{k T}{h}\right)+\frac{\Delta S_{\Delta \text { ppurent }}{ }^{\dagger}}{R}$

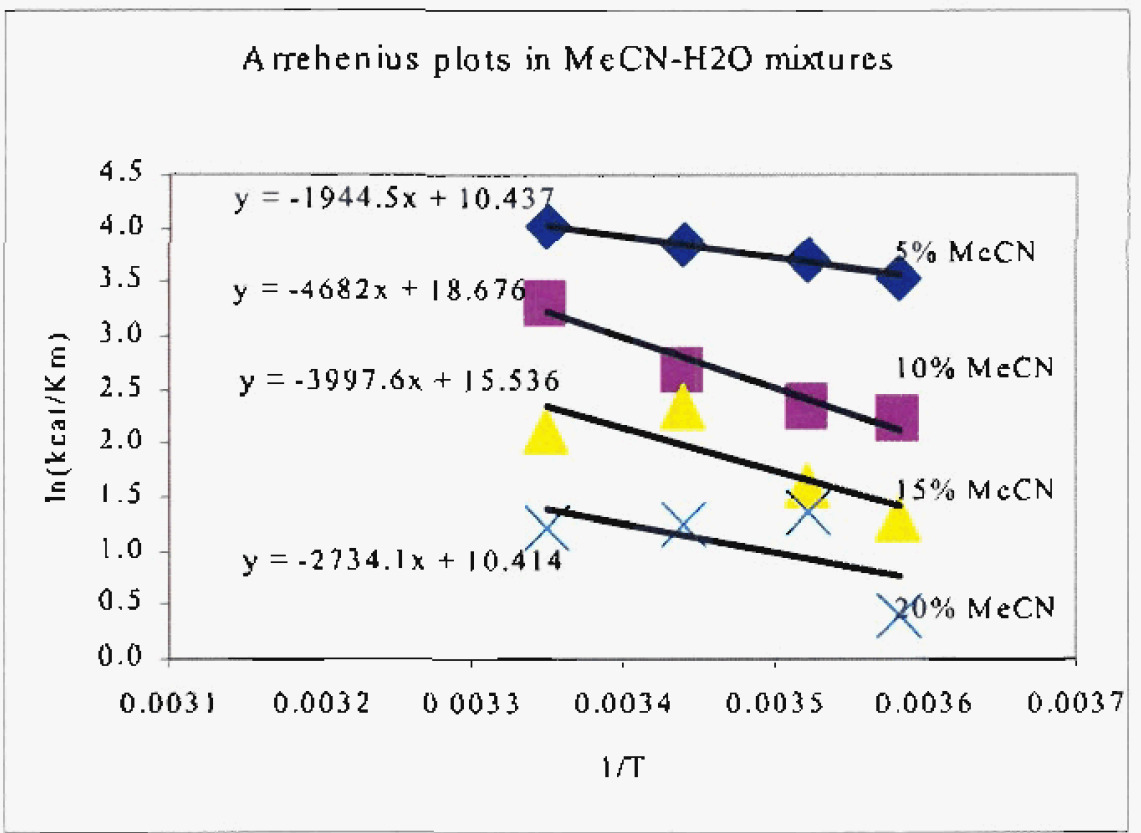

Figure 5. Arrehenius plots for pyrene conversion in various acetonitrile-water mixtures.

The effect of the change in the transmission coefficient due to the solvent and the temperature on the observed change in entropy is lumped into the apparent entropy change parameter $\left(\Delta S_{\text {cyponimi }}{ }^{\dagger}\right)$. The frequency $[v=(k T / h)]$ at room temperature $\left(22^{\circ} \mathrm{C}\right)$ is $6.14 \times 10^{12} \mathrm{sec}^{-1}$. The change in free energy for the enzymatic conversion of pyrene at various solvent concentrations was calculated using equation 6 and is given in Table 2 .



Table 2. The observed free energy change for pyrene conversion. $\Delta \mathrm{G}_{\text {obs }} \ddagger$ 


\begin{tabular}{|l|l|}
\hline $5 \%$ acetonitrile* & 15.01 \\
\hline $10 \%$ acetonitrile & 15.62 \\
\hline $15 \%$ acetonitrile & 16.10 \\
\hline $20 \%$ acetonitrile & 16.59 \\
\hline
\end{tabular}

* The solvent mixture contained pH 6.1 potassium phosphate buffer in addition to acetonitrile.

The results show that the observed free energy of activation increases as the solvent concentration increases. This can be explained by the following analysis. Let us consider the various processes that have to occur for the enzymatic reaction to take place. As shown in Figure 6 , the first step is the binding of the substrate to the enzyme active site. A favorable binding interaction between the two entities, substrate and enzyme is necessary for the first step to occur. The observed free energy change for the reaction $\Delta \mathrm{G}_{\mathrm{obs}}{ }^{*}$ is a sum of the binding energy and the intrinsic activation energy for transition state formation (Equation 7). A negative value of the binding energy indicates good substrate-enzyme binding. Such a favorable binding energy will result in a decrease in the observed activation energy $\Delta \mathrm{G}_{\text {obs }}{ }^{\ddagger}$.

$$
\Delta \mathrm{G}_{\mathrm{obs}}^{\ddagger}=\Delta \mathrm{G}_{\mathrm{B}}+\Delta \mathrm{G}_{\mathrm{T}}^{\ddagger} \quad \ldots 7
$$

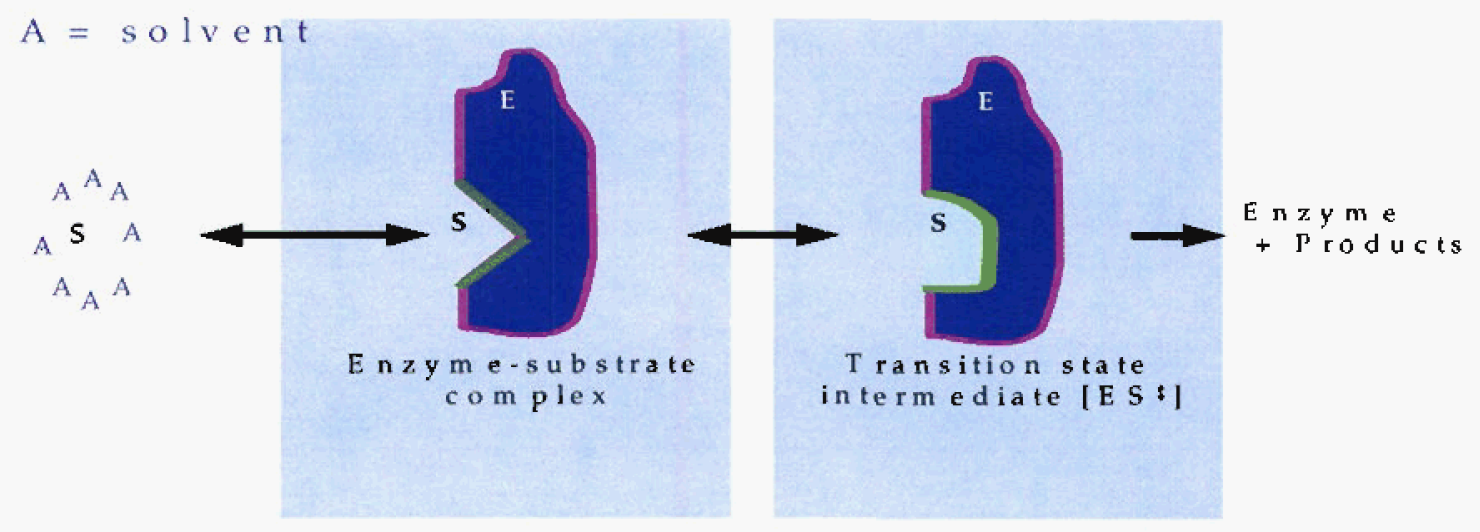

Figure 6. Pictorial representation of substrate partitioning between solvent and enzyme active site followed by the transition state formation and finally, conversion to products.

Figure 7 hows the effect of changing binding energy on the observed activation energy. The binding energy is a function of the solvent or solvent mixture used. In case of pyrene conversion in organic solvents or aqueous-solvent mixtures, increasing the concentration of acetonitrile in the solvent mixture will result in increased solubility of pyrene. This creates an unfavorable situation for the partitioning of pyrene into the enzyme active site from the solvent phase. It is difficult to calculate the binding energy, especially since the structure of pyrene-cytochrome $c$ complex has not been determined and is out of the scope of this work. The transfer free energy $\left(\Delta \mathrm{G}_{\mathrm{S}}\right)$ for pyrene transfer from one solvent to another, however, can be calculated. Table 3 shows the transfer free energies for pyrene using pure acetonitrile as a reference. The $\Delta \mathrm{G}_{\mathrm{S}}$ represents a change in free energy for transfer of pyrene from a given solvent to the reference solvent (Equation 8). 
$\Delta G_{s}=-R T \ln \left(S_{\text {rejerence }} / S_{\text {solwem }}\right)$



$\ldots 8$

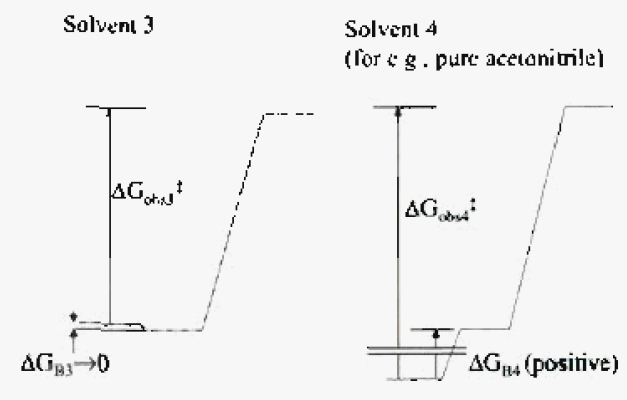

Figure 7. Free energy plot for enzymatic conversion of pyrene. $\Delta G_{B}=$ binding free energy, $\Delta G_{o b s}=$ Measured free energy change, $\Delta G_{\mathrm{T}}=$ Free energy change for transition state formation. The subscripts 1 to 4 represent different solvents/mixtures.

Transfer of pyrene from say, $5 \%$ pyrene to pure acetonitrile has a $\Delta G_{S}$ of -5.32 indicating a favorable partitioning into the pure acetonitrile phase. Use of $\Delta G_{S}$ in place of $\Delta G_{\mathrm{B}}$ gives a qualitative comparison of the effect of solvent on observed free energy. In order to determine the relationship between the two terms, $\Delta \mathrm{G}_{\mathrm{B}}, \Delta \mathrm{G}_{\mathrm{T}}^{\dagger}$ and the observed free energy change, Linear free energy relationships (LFER) were plotted with solvent concentration as the variable (Figure 8) The plot shows that an increase in the observed activation energy is proportional to the change in $\Delta \mathrm{G}_{\mathrm{S}}$ the transfer free energy, which is equivalent to the binding free energy. This suggests that the change in reaction rates (and therefore the observed activation energy) is due to the effect on the ground state of the reactants. A solvent mixture with higher pyrene solubility essentially keeps the substrate from partitioning into the enzyme active site. 


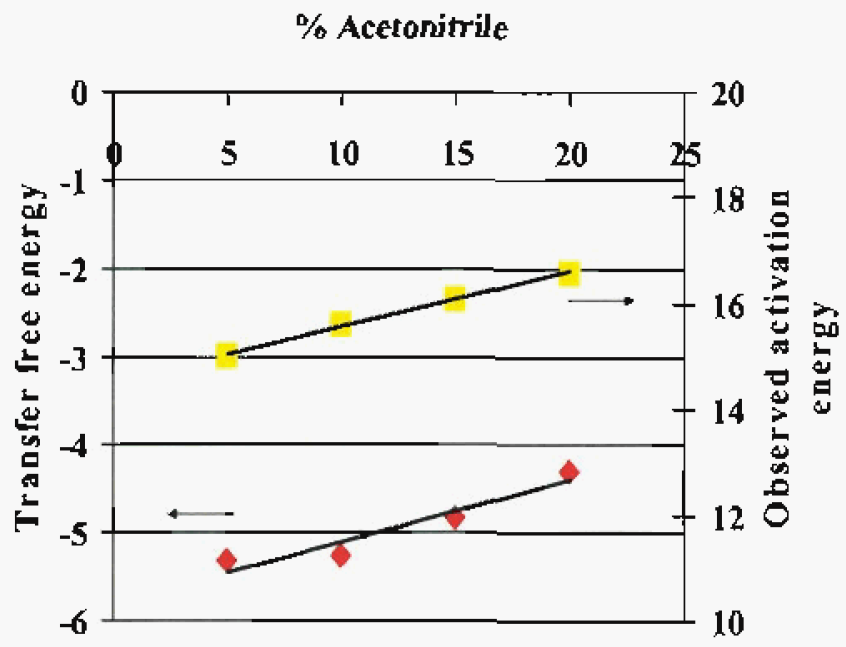

Figure 8. Observed activation energy for pyrene conversion (squares) and transfer free energy (diamonds) for solvation of pyrene from a given solvent / mixture to pure acetonitrile.

Further, an increasing trend in the observed activation energy with the acetonitrile concentration suggests that at some threshold acetonitrile concentration, the reaction will stop occurring due to a very high activation energy requirement. This has been observed experimentally at $50 \%$ acetonitrile. The intrinsic activation energy for the reaction was also determined by using $\Delta G_{\mathrm{S}}$ in place of $\Delta G_{B}$ (equation 7). A relatively constant $\Delta G_{T}^{+}$over the solvent concentrations studied suggests that the transition state is relatively unaffected by the change in acetonitrile concentration. The intrinsic differential activation energy $\left(\Delta \Delta \mathrm{G}^{*}\right)$ was also calculated based on the approach of $\mathrm{Kim}$ et.al., [16] using $20 \%$ acetonitrile as the standard solvent, and a similar result was obtained. Since the solvent mixtures used had different dielectric constants (Table 3), the lack of change in the intrinsic activation energy indicates that the solvent polarity has little effect on the transition state intermediate compared to its effect on the ground state of the reactants. Thus, for enzymatic transfomation of pyrene in organic media, the substrate binding to the catalytic active site is the controlling factor in determining the feasibility of the reaction.

\subsection{Chemical modification of peroxidases}

Cytochrome $c$ was modifjed by various methods to improve its activity in organic media. The goal was to either make the protein soluble in organic phase by attachment of hydrophobic polymers or to make its active site hydrophobic by attachment of small groups near the active site. 


\begin{tabular}{|c|c|c|c|c|c|}
\hline & $\begin{array}{l}\text { Solubility of } \\
\text { pyrene (mM) }\end{array}$ & $\Delta G_{S}$ & $\Delta \mathrm{G}_{\mathrm{T}}{ }^{\ddagger}$ & $\Delta \Delta G^{*}$ & $\varepsilon$ \\
\hline $5 \%$ acetonitrile & 0.0011 & -5.32 & 20.33 & 3.74 & 76.48 \\
\hline $10 \%$ acetonitrile & 0.0012 & -5.27 & 20.88 & 4.29 & 74.47 \\
\hline $15 \%$ acetonitrile & 0.0025 & -4.83 & 20.93 & 4.34 & 72.45 \\
\hline $20 \%$ acetonitrile & 0.0064 & -4.29 & 20.88 & 4.29 & 70.43 \\
\hline $30 \%$ acetonitrile & 0.0532 & -3.04 & & & \\
\hline Pure acetonitrile & 9.5020 & 0.00 & & & \\
\hline
\end{tabular}

\subsubsection{PEG modification:}

Modification of cytochrome c (bovine heart) was done using a methoxy polyethylene glycol succinimidyl succinate (MPSS) at a 50 molar excess of MPSS. The reaction vessel contained $4 \mathrm{~g}$ cytochrome $\mathrm{c}+94 \mathrm{~g}$ MPSS $+4 \mathrm{mM}$ pH 6.1 phosphate buffer $60 \mathrm{mM}$. The contents were mixed for 48 hours at $40 \mathrm{C}$. The modified cytochrome $\mathrm{c}$ was then purifted using size-exclusion chromatography. The sample was passed through a $1.5 \times 45 \mathrm{~cm}$ Sephadex $\mathrm{G} 75$ column at a flow rate of $0.5 \mathrm{~mL} /$ minute. About 50 fractions were collected, two mL each and the absorbance at 280 and 409 nm was measured. About $90 \%$ of the cytochrome $c$ was modified. The peak with modified cytochrome $c$ (MPSS-cyt c) was pooled and lyophilized over a 24 hour period. The solubility of the MPSS-cyt $\mathrm{c}$ was determined by dissolving $2 \mathrm{mg}$ of lyophilized powder in $1 \mathrm{~mL}$ of toluene. The mixture was shaken for one minute and held for one hour, after which a spectrum of the solution was measured. A spectrum similar to an aqueous solution of cytochrome $c$ was observed giving a peak comesponding to the heme at $409 \mathrm{~nm}$ quantified at $2 \mathrm{mg} / \mathrm{ml}$. This indicates that the MPSS-cyt $c$ was soluble in toluene up to $2 \mathrm{mg} / \mathrm{ml}$.

The modified cyt $c$ was assayed using the pinacyanol chloride and the pyrene assay. The results of the pinacyanol chloride assay are shown in Figure 9. The PEG bound to cytochrome $c$ apparently keeps the enzyme from being inactivated by the solvent beyond $50 \%$ acetonitrile and prevents reduction of activity at higher solvent concentrations. The results for pyrene conversion are shown in Figure 11 below.

\subsubsection{Alkyl modification:}

The modification of cytochrome $c$ with polymers like PEG results in their attachment at the surface of the protein. The results from the thermodynamic analysis suggested that making the active site hydrophobic or more favorable to binding of the substrate will improve activity in organic media. The altachment of alkyl groups therefore was initiated. The procedure used alkyl aldehydes which were reductively linked to the lysine groups within the protein giving, for example a $\mathrm{CH}_{3} \mathrm{CH}_{2}$-ligand using acetaldehyde as the modifyirg agent. Additionally, due to the relatively small size of these groups, they could potentially diffuse into the interior of the protein and possibly attach at the lysine residues near the heme active site. As shown in Figure 10, the cytochrome $c$ has 19 lysine residues, seven of which are in close proximity to the heme. 


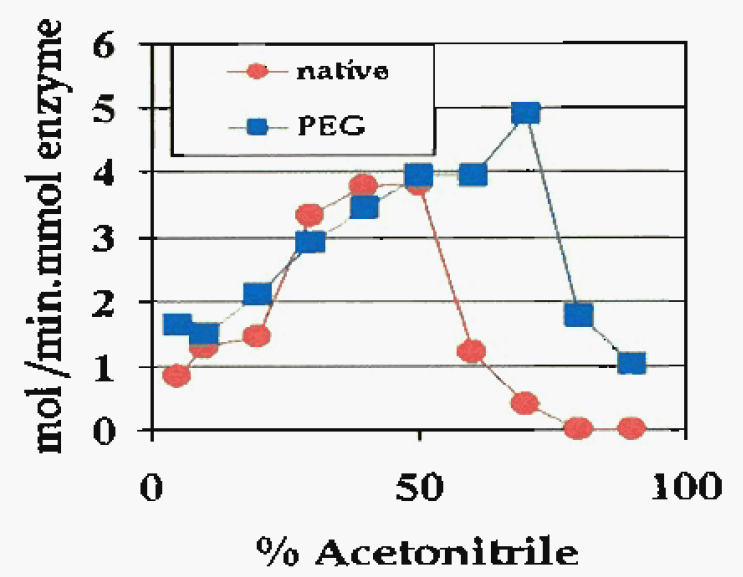

Figure 9. Bioconversion of pinacyanol chloride by native (unmopdified) and PEG-cyt $c$ at various concentrations of acetonitrile.

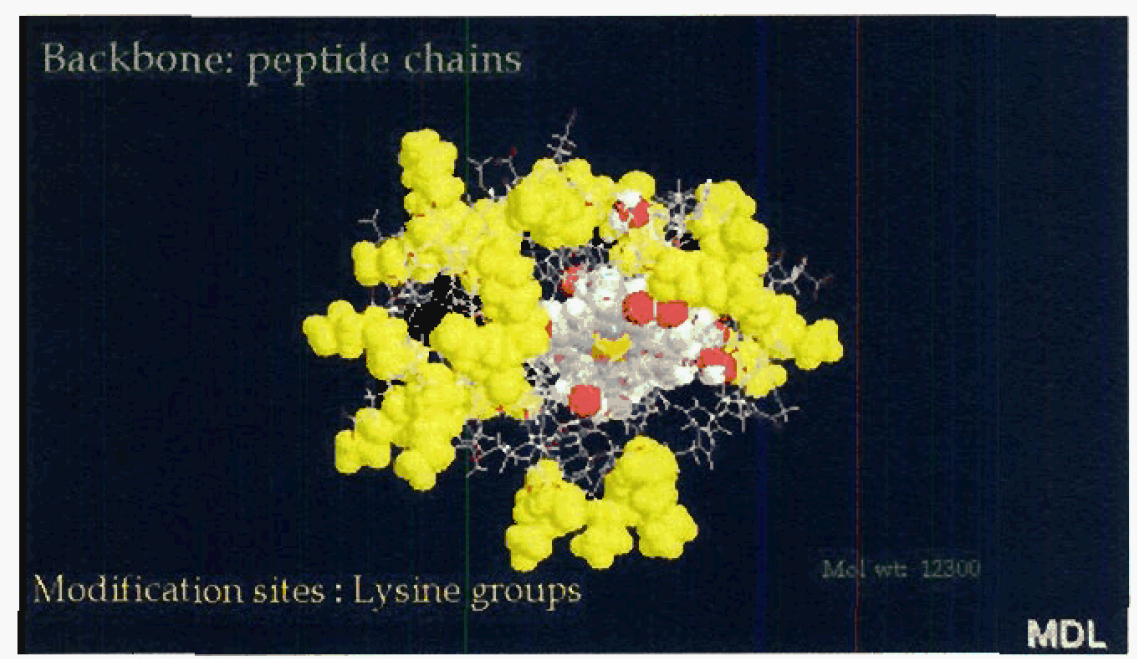

Figure 10. Ball and stick structure of cytochrome $c$ with lysine residues and the heme shown as colored spheres.

Results for the pyrene conversion by alkyl modified cytochrome $c$ are shown in Figure 11 . The results indicate an increased activity for the modified protein vs. the native protein at all acetonitrile concentrations. Further, the concentration of acetonitrile at which the catalyst shows maximum aclivity has also increased as a result of the alkyl modification. Assuming that the lysine residues near the active site are modified, this suggests that by increasing the hydrophobicity of the protein, it is possible to make it active at higher solvent concentrations $20 \%$ acetonitrile vs. $10 \%$ acetonitrile for the native/PEG modified protein. This is a very important inference from these experiments. In addition to PEG and alkyl modifications, a 
combined modification was also carried out with PEG and alkyl agents. This was done by performing the PEG modification first followed by the alkyl modification. This enables the PEG attachment at the surface and alkyl modification at the lysine residues within the protein. This modification imparts the protein characteristics of both the modifications, although the effect is not cumulative in terms of overall activity. However, this protein has higher activity at greater than $50 \%$ acetonitrile as well as the maxima in activity is shown at the higher solvent concentration $(20 \%)$.

Pyrene conversion

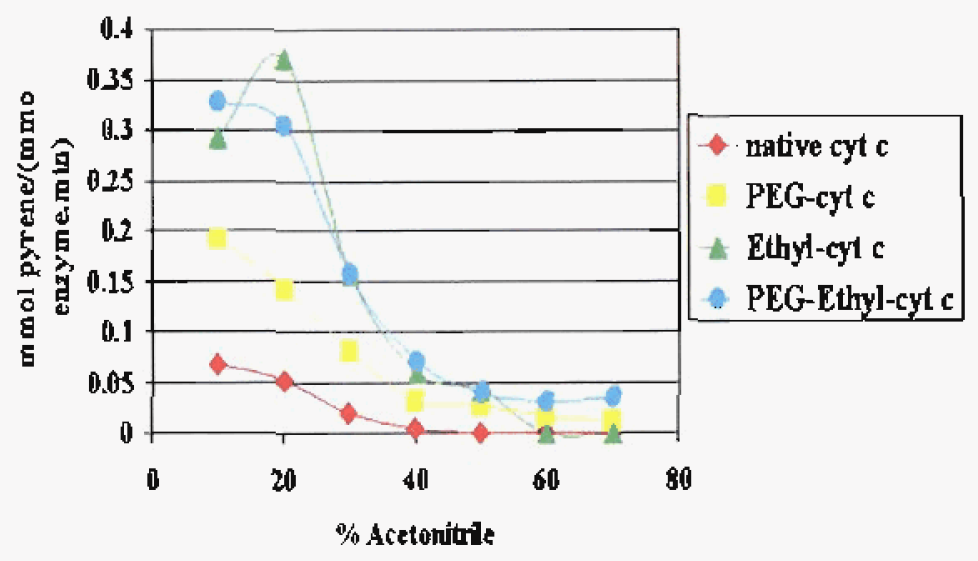

Figure 11. Comparison of pyrene conversion by PEG-cyt c and Ethyl cyt c.

In addition to the ethyl modification, other alkyl groups were also attached to the cytochrome $c$ molecule. Formaldehyde and propionaldehyde were used to attach methyl and propyl groups respectively. The results (Figure 12) show that there is an optimum chain length for activity improvement. In case of pinacyanol chloride which is a longer molecule than pyrene, the ethyl modification is optimum, while for the pyrene, the ethyl and methyl modifications improve the activity to the same extent.
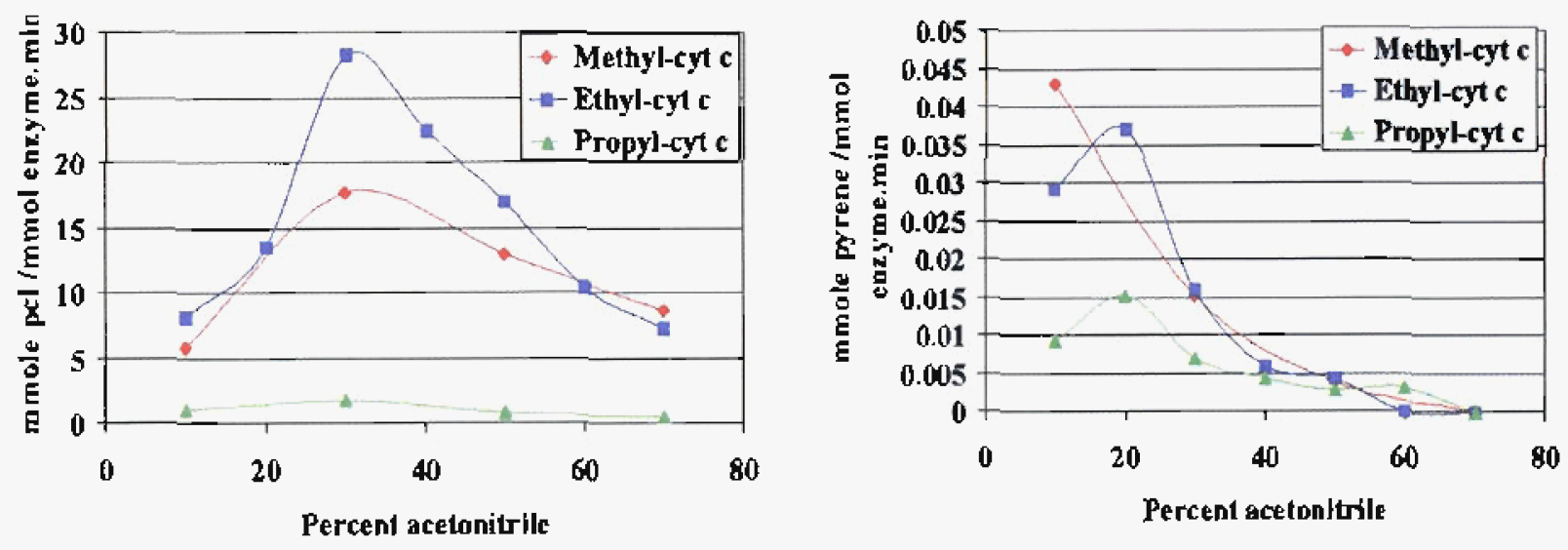

(a)

(b) 
Figure 12. Effect of alkyl chain length on activity of modified cytochrome c. (a) Conversion of pinacyanol chloride, (b) Conversion of pyrene.

Although, the chemical modification procedure improves activity of the protein in organic solvent mixtures, the extent of improvement possible with such modifications is limited due to the limited sites available for modification and since the point of attachment cannot be selected to give the best activity. In order to achieve this, altemate methods capable of manipulation of the sites of attachment themselves may be useful. Genetic techniques, which can modify the primary protein structure and place the lysine residues at required positions may be applicable. This approach was therefore explored and is discussed below.

\subsection{Genetic engineering of lignin peroxidase:}

Additional proteins were screened to select the best candidate for genetic modification for further activity improvement. Although the protein cytochrome $c$ has significant activity for PAH conversion, the activity is lower than the protein lignin peroxidase (LiP).

6.4.I Cloning lip into Pichia pastoris: The lip gene was cloned into a commercial expression system 'Easy Select Pichia Expression Kit', available from Invitrogen. The gene was inserted for as well as extracellular expression ( $\mathrm{PPICZ} \alpha \mathrm{ABC}$ and pPICZABC) via the $\alpha$ factor prepro peptide from Saccharomyces cerevisiae and the native secretion signal, respectively. The three plasmids $A, B, C$ were one basepair apart. The following plasmids were successfully generated: pPICZ $\alpha \mathrm{B}, \mathrm{pPICZ} \alpha \mathrm{C}, \mathrm{pPICZA}, \mathrm{pPICZC}$. Sequence frame analysis for protein expression indicated that from the $\alpha$ series, $\mathrm{PPICZ} \alpha \mathrm{A}$ was the only plasmid which could successfully produce an active protein, while all three plasmids from the other series (using the native secretion signal) could produce an active protein, since its expression was controlled by its own start codon (ATG). Several colonies of P. pastoris were picked from the different transformants and tested for activity. A minimal media as well as the media recommended by Invitrogen (Buffered Minimal Glycerol/methanol, BMG/BMM) was used. The minimal media was a $25 \%$ strength BMG/BMM. The strain was usually grown in glycerol medium, followed by an induction with methanol. Media optimization was also conducted by adding calcium and iron, since the protein lignin peroxidase has iron heme and calcium as ligands bound within the protein. The activity of the clones was measured by the ABTS assay as well as the veratryl alcohol assay. The activity was found to be extremely low and barely measurable. Since several factors could influence the activity, further analysis was conducted by growing the recombinant $\mathrm{LiP}$ ( $\mathrm{rLiP}$ ) clones in a $1 \mathrm{~L}$ bioreactor, controlling the $\mathrm{pH}$, oxygen level, temperature and agitation.

A control reactor was also run with a strain containing the pPICZ plasmid but no gene insert. The activity results from the reactor run are shown in Figure 13. 


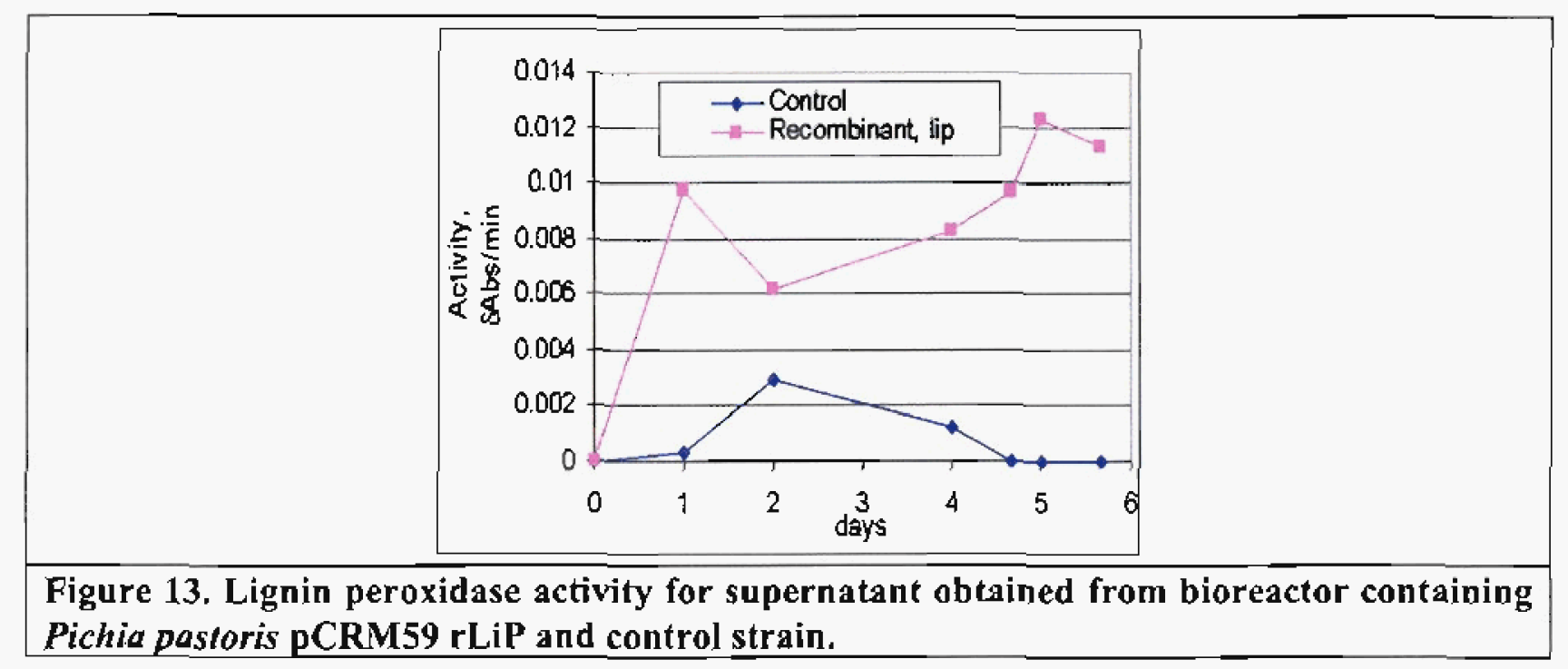

The results indicate the presence of peroxidase activity (ABTS assay), however the activity is very low for enabling detection in microwell plate samples, needed for enzyme improvement. In order to investigate the low activity observed, some clones were grown for isolating protein. Some of the plasmids used enabled attachment of polyhistidine tag at the C-terminal. The cells were grown in a $1 \mathrm{~L}$ batch and the supernatant as well as the cell cytoplasmic and membrane fraction were examined for the presence of rLiP. The supematant was found to contain negligible rLiP protein. The cell membrane fraction was found to contain a peak on UV-vis spectrum at 400 $\mathrm{nm}$ corresponding to a herne, which may be the $\mathrm{rLiP}$, since there was no such peak on the control sample. Further analysis by sodium dodecyl sulfate- polyacryl amide gel electrophoresis (SDSPAGE) was also conducted. The cell extract and the membrane fraction was found to contain a band corresponding to $\sim 42 \mathrm{~K}(\mathrm{LiP}=42 \mathrm{KDa})$, which may potentially be the recombinant protein (Figure 14).

These resuits indicated that there may be a portion of the rLiP which was not exported to the exterior of the cells and may have precipitated within the cells. However, the total $r$ LiP protein produced was still very small, therefore, further attempts were directed towards increasing the protein production.

6.4.2 Increasing expression of rLiP: Two approaches were taken to further investigate and improve the rLiP expression. Firstly, the protein was fused with another protein known to express in Pichia pastoris namely $\beta$-galactosidase ( $\beta$-gal) encoded by lacZ gene. The lip gene was cloned behind the lac $Z$ gene under control of the $\beta$-gal promoter. The presence of the fusion protein was then easily detected by the $\beta$-gal assay, i.e. using the blue-green assay with $\beta$ galactoside. A few colonies were isolated which reported positive activity in the $\beta$-gal assay, however, after transferring the colony for re-culturing, no growth was observed after repeated trials. This indicated that the plasmid was nol stable, therefore this approach had to be abandoned. 


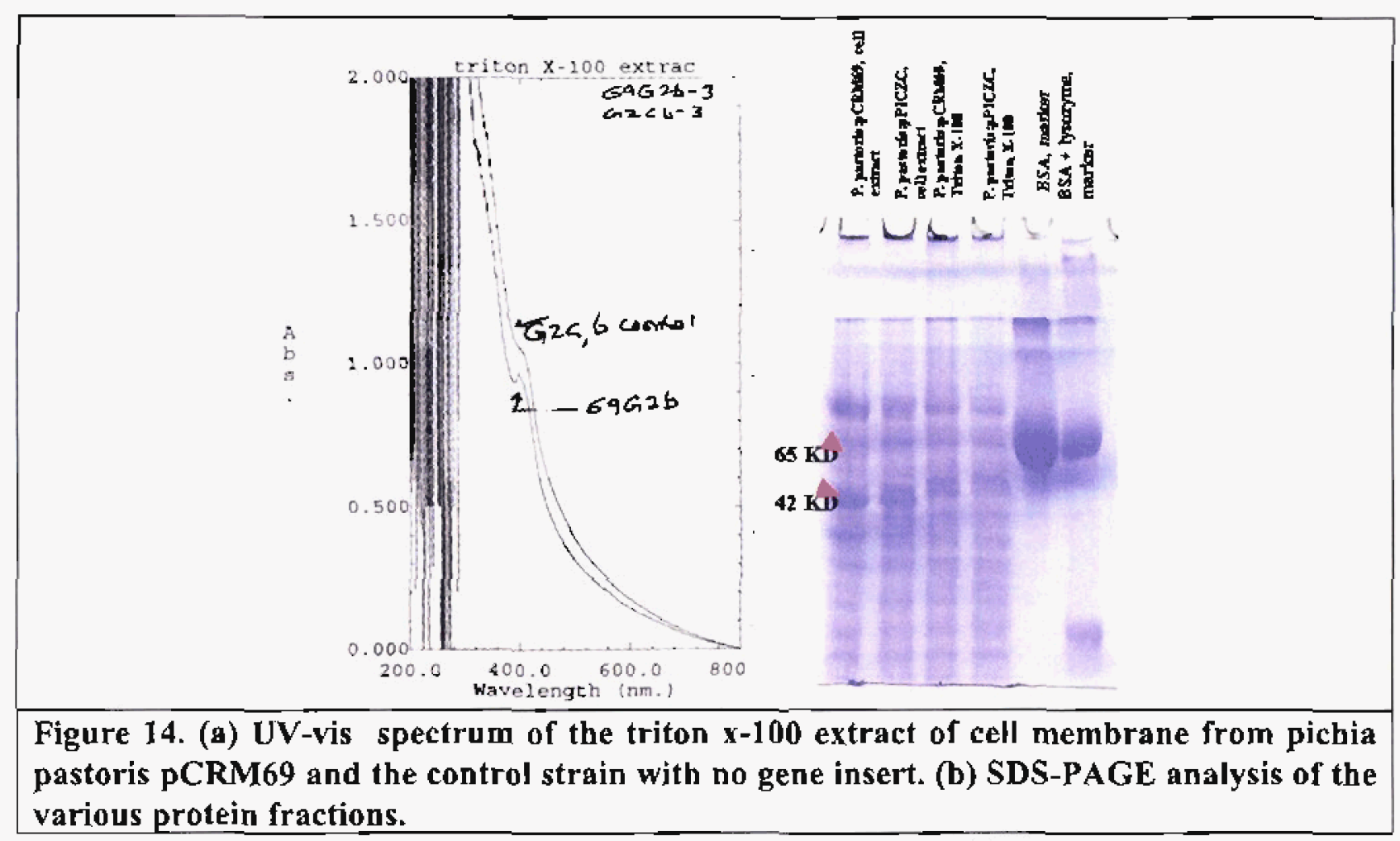

In the second approach, the codon usage in lip gene was partially modified to reflect the codon usage by Pichia pastoris. The lip gene (from Phaenerocheate chrvsosporium) has a GC content of $60 \%$ as opposed to $48 \%$ for the Pichia pastoris strains. Therefore, it was hypothesized that reducing the GC content may promote better expression. This was done by changing $\mathrm{GC}$-rich portions of the original gene. In all, 24 bases were changed in three regions of the gene, without changing the amino acid sequence, resulting in about $57.9 \% \mathrm{GC}$ content. This was done by generating three pairs of primers with a maximum possible AT content. The remaining gene fragments were generated by PCR. Two of the three gene modifications were successfully produced. However, the final recombination and cloning into Pichia pastoris could not be completed due to lack of time and funding. A complete analysis of clones prepared by removing the codon bias may potentially allow expression of lip in Pichia pastoris.

\section{Conclusions}

Investigations into the activity of peroxidase enzymes in organic media for conversion of polyaromatic hydrocarbons demonstrated that while partial oxidation to quinones occurred in $10 \%$ mixtures of organic solvent in aqueous buffers, no conversion takes place in pure solvents. A thermodynamic analysis of the enzymatic PAH conversion in organic media revealed lack of effective interaction between the substrate and enzyme as the cause for low to negligible activity. This indicated a need for higher hydrophobocity of the enzyme active site to bind highly hydrophobic molecules such as pyrene. The protein cytochrome $c$ was modified by attachment of two hydrophobic groups: polyethylene glycol (PEG) and an alkyl group. Alkyl groups, being small could be atached at interior locations within the core of the enzyme and possibly near the active site. Increase in the enzyme activity at higher solvent concentrations indicated potential of this strategy for effective enzyme-substrate interaction. Further improvements in enzyme activity called 
for other diverse methods due to the unavailability of sufficient chemical modification sites. Genetic techniques were therefore explored for further improvements. These experiments focused on cloning of a gene for the fungal enzyme lignin peroxidase (lip) into yeast Pichia pastoris, which would allow easy manipulation of the gene. However, differences in the fungal and yeast cellular machinery impeded significant expression of the fungal enzyme. Several methods to improve expression including media optimization, addition of heme ligand, use of different host strains and directed evolution via error-prone PCR were explored. However, the expression levels did not change significantly. Examination of the cell supernatant and cell membrane fraction for additiona] protein indicated that some of the protein may be present intracellularly, but the overll levels were still low. This indicated a problem at the transcription level. Further strategies including removal of codon bias were examined but these experiments could not be completed due to time and funding limitations. Additional work is therefore necessary to better understand the problems with expression of such proteins in heterologous hosts and to allow protein engineers to design proteins that would carry out conversion of hydrophobic substrates in organic media.

\section{Current State and Assessment}

The project goal was to assess potential of enzymes as biocatalysts for petroleum upgrading. Besides the work conducted during this project and research conducted at other nationa] laboratories as part of the NPTO program funding this project, the technical knowledge gained in the area of non-aqueous enzymology during the last three years was also applied during the course of this project. This knowhow has been essentially obtained from studies of enzymes such as lipases for esterification and transesterification reactions. In these studies, several critical parameters affecting the activity and stability of enzymes in solvents were identified. Such parametric effects were applied to study the effect of enzyme of interest in petroleum bioprocessing. However, the reasons for inactivation and instability of the peroxidase enzymes relevant to petroleum processing as compared to the other enzymes were found to be different. The main parameter affecting activity of enzymes for application in petroleum processing was found to be the total inability of enzymes to bind the substrates of interest in an organic environment. Therefore, the need for demonstrating the feasibility of an enzyme-based process for petroleum processing required development of an enzyme which could effectively bind the substrates of interest. This can potentially be done by designing an enzyme with high hydrophobicity. Such enzymes do not usually occur in nature but for few exceptions. These exceptions typically include proteins involving binding of steroids, long chain fatty acids (> C16) and possibly polyaromatic hydrocarbons from PAH degrading bacteria. This project has shown the proof of principle for improving enzyme activity using the concept of increased hydrophobicity at the active site via chemical modification. Further improvements will require significant efforts in protein engineering. The current state of research in protein engineering allows some predictions of modifications to allow binding improvements, however, the process of developing a protein exactly fitting the needs of petroleum processing has to be done, at least at this stage, via a trial and error approach, which was used in the current project. Further work in this area can potentially provide biocatalysts suitable for petroleum applications.

\section{Questions to be answered}

The main question that has risen from the work conducted during this project is: 
Can one design and develop a protein which can bind a polyaromatic entity effectively enough in an organic media to allow a biocaralytic reaction?

\section{Inventions}

A subject invention was submitted for expression of lignin peroxidase by a heterologous host. The patent was not pursued since further work is necessary to completely confirm the preliminary results obtained during this work.

\section{Commercialization Possibilities}

Commercialization of enzyme based processing of petroleum requires additional research in the area of biocatalyst development. At least 3-5 years of further research is required to achieve this goal. Therefore, the commercialization of such tectuologies is at least five years away.

\section{Plans for Future Collaboration}

A new project in the area of biocatalyst development has been initiated in collaboration with ChevronTexaco. In this project, enzymes capable of relaining activity in organic media and at slightly higher temperatures $\left(60-90^{\circ} \mathrm{C}\right.$ ) will be explored. Enzymes capable of PAH bioconversion such as those from PAH degrading bacteria and those capable of xenobiotic compound metabolism, for example, cytochrome P450 and other oxidase enzymes will be studied. Work will be initiated with cytochrome P450s already expressed in a host allowing genetic manipulation, for example, E. coli. Genetic modifications will then be cartied out using PAH oxidation as the reaction of interest to improve and/or activity in organic media, while optimizing for operation in the thermophilic range.

\section{Acknowledgements}

The authors would like to acknowledge the technical contributions of Miguel Rodriguez, Jr (genetic modifications) and Catherine Cheng, Laura Flatau and John Cosgrove (chemical modifications). Technical direction provided by the industrial contributors, Dr. Robert Shong and Dr. Daniel Hagewische, ChevronTexaco; and Dr. Gary Jenneman, Phillips Petroleum Company; is greatly appreciated. The authors would like to acknowledge Dr. Nancy, DaSilva for providing the lignin peroxidase gene and Dr. M. Tien for permission to use it.

\section{References}

1. Hunt, J.M., Petroleum Geochemistry and Geology. 1979, San Francisco: Freeman.

2. Strausz, O.P., T.W. Mojelsky, and E.M. Lown, The molecular structure of asphaltene: an umfolding story, Fuel, 1992. 71: p. 1355-1363.

3. Folsom, B.R., et al., Microbial desulfurization of olkylated dibenzothiophenes from a hydrodesulfurized middle distillate by Rhodococcus erythropolis 1-19. Appl and Environ. microbiol., 1999. 65(1 l): p. 4967-4972.

4. Kaufman, E.N. and A.P. Borole, Removal of hetervatoms and metals from heary oils by bioconversion process. 1999, Oak Ridge National Laboratory: Oak Ridge. 
5. Kaufman, E.N, et al., Sulfur Specificity in the Bench Scale Biological Desulfurization of Cride Oil by Rhodococcus IGTS8. J. Chem. Technol. \& Biotechnol., 1999. 74: p. 10001004.

6. Vazquez-duhalt, R., D.W.S. Westlade, and P.M.U.A. Fedorak, Lignin Peroxidase Oxidation of Aromatic Compounds in Systems Containing Organic Solvents. Appl. \& Envir. Microbiol., 1994. 60(2): p. 459-466.

7. Wang, P., C.A. Woodward, and E.N. Kaufman, Poly(ethylene glycol)-modified ligninase enhances pentachlorophenol biodegradation in water-solvent mixtures. Biotechnology and Bioengineering, 1998: p. submitted for publication.

8. Woodward, C.A. and E.N. Kaufman, Enzymatic catalysis in organic solvents: polyethylene glycol modified hydrogenase retains its sulfhydrogenase activity in toluene. Biotechnology and Bioengineering, 1996. 52(3): p. 423-428.

9. Friedman, m., L.D. Williams, and M.S. Masi, Reductive dealkylation of proteins with aromatic aldehydes and sodium cyanoborohydrate. Int. J. Peptide Protein Res., 1974. 6: p. 183-185.

10. Cereghino, J.L. and J.M. Cregg, Heterologous Protein Expression in the Methylotrophic Yeast Pichia Pastoris. Microbiology Reviews, 2000. 24: p. 45-66.

11. Sambrook, Y., E.F. Fritsch, and T. Manjatis, Molecular Cloning: a laboratory manual. 2nd. ed. 1989, Cold Spring Harbor, N.Y: Cold Spring Harbor Laboratory Press.

12. Zhao, H. and F. Amold, Combinatorial Protein Design: Sirategies for screening protein libraries. Current opinion in structural biology, 1997. 7: p. 480-485.

13. Gershenson, A. and F.H. Amold, Genetic Engineering Principles and Methods. Vol. 22. 2000: Plenum Press, in press.

14. Vazquez-Duhalt, R., D.W.S. Westlake, and P.M. Fedorak, Cytochrome $c$ as a biocalalyst for the oxidation of thiophenes and organosulfides. Enzyme Microb. Technol, 1993. 15(6): p. 494-499.

15. Fersht, A., Siruchure and Mechanism in Prolein Science. 1999, New York: W. H. Freeman and Company. 631.

16. Kim, J., D.S. Clark, and J.S. Dordick, Intrinsic effects of solvent polarity on enzymic activation energies. Biotech. \& Bioeng., 2000. 67(1): p. 112. 